\title{
Effect of intravenous midazolam on intracranial pressure during endotracheal suctioning in patients with severe head injury
}

\author{
Metilda Robin, Teenu Xavier, T. Anjusha ${ }^{1}$, Merin L. Kuriakose, Deepak Agrawal²
}

\begin{abstract}
Background: Patients with severe traumatic brain injury (TBI) require elective ventilation and sedation to decrease intracranial pressure (ICP) and any increase in ICP may be detrimental for the outcome in these patients. Methods: This prospective study was done in a neurotrauma intensive care unit ( ICU ) of a level I trauma centre in India over a one month period.All adult male patients with severe TBI on mechanical ventilation and monitored for ICP were included in this study. Baseline ICP was measured before starting endotracheal (ET) suctioning and serial readings were taken during and after ET suctioning. Patients were divided into two groups (control and intervention) with intervention group receiving intravenous bolus dose of $2 \mathrm{mg}$ of midazolam before ET suction. Results: A total of 20 patients were enrolled during the study period. Both groups were well matched with regards to age and admission Glasgow coma scale (GCS). There were 10 patients in the midazolam group and 10 patients in the control group.The mean rise of ICP following ET suctioning in control group was found to be $24.1 \mathrm{~mm} \mathrm{Hg} \pm \mathrm{II}$.I as compared to $18.25 \mathrm{~mm} \mathrm{Hg} \pm-9.29$ in the midazolam group $(P<0.05)$. Conclusions: Significant rise in ICP from baseline occurs following ET suctioning in ventilated, severe TBI patients. Our study suggests that additional intravenous bolus of midazolam prior to suctioning may significantly reduce the rise in ICP and should be practiced by ICU nurses.
\end{abstract}

Key words: Endotracheal suctioning, intracranial pressure, midazolam, severe traumatic brain injury

\section{INTRODUCTION}

Maintenance of normal intracranial pressure (ICP) remains the cornerstone of management in severe traumatic brain injury (TBI) patients. ${ }^{[1]}$ However, various procedures such as positioning, assessment of Glasgow

Nursing Officer, All India Institute of Medical Sciences, New Delhi, India, ${ }^{1}$ Registered Nurse, Metro West Hospital, Natick, USA, ${ }^{2}$ Department of Neurosurgery, All India Institute of Medical Sciences, New Delhi, India

Address for correspondence:

Dr. Deepak Agrawal, Department of Neurosurgery, JPNATC,

All India Institute of Medical Sciences, New Delhi, India.

E-mail: drdeepak@gmail.com

\begin{tabular}{|l|l|}
\hline \multicolumn{2}{|c|}{ Access this article online } \\
\hline Quick Response Code: & Website: \\
\hline & www.jnaccjournal.org \\
\cline { 2 - 2 } & \\
\hline
\end{tabular}

coma scale (GCS) and endotracheal (ET) suctioning may be accompanied by deleterious variation in mean arterial pressure (MAP), ICP and cerebral perfusion pressure (CPP).

Adequate analgesia, sedation and muscle paralysis (using barbiturates) are usually used to prevent such undesirable increases in ICP during various procedures. ${ }^{[2]}$ This has also led to a search of agents with shorter duration of action and fewer side effects than barbiturates. ${ }^{[3]}$ Midazolam is a water-soluble, short-acting benzodiazepine that has been recommended as an effective IV agent for maintaining sedation as well as for induction of anaesthesia. ${ }^{[4]}$

This is an open access article distributed under the terms of the Creative Commons Attribution-NonCommercial-ShareAlike 3.0 License, which allows others to remix, tweak, and build upon the work non-commercially, as long as the author is credited and the new creations are licensed under the identical terms.

For reprints contact: reprints@medknow.com

How to cite this article: Robin M, Xavier T, Anjusha T, Kuriakose ML, Agrawal D. Effect of intravenous midazolam on intracranial pressure during endotracheal suctioning in patients with severe head injury. J Neuroanaesthesiol Crit Care 2017;4:167-9. 
The current study was designed to assess the effectiveness of midazolam in decreasing the rise of ICP during ET suctioning among severe TBI patients.

The secondary objectives of the study were:

- To determine the variation in ICP after administering bolus dose of Midazolam

- To compare the variation in ICP during ET suctioning both in the experimental and control group

- To determine the mean duration of time taken to return to baseline ICP after ET suctioning.

\section{METHODS}

A prospective, pilot study was conducted over 1 month (January 2014) using experimental research design after obtaining permission from the Ethics Committee of the Institute. Informed consent was obtained from the family members of patients. The null hypothesis was that the mean increase in ICP in experimental group will not be significantly lower than control group during ET suctioning.

\section{Setting}

Jai Prakash Narayan Apex Trauma Center of All India Institute of Medical Sciences is a level 1 trauma centre in Delhi, India. This study was conducted in the neurotrauma Intensive Care Unit in severe TBI (GCS $\leq 8$ ) adult (age 18-60 years) male patients who were on mechanical ventillator and undergoing ICP monitoring. As per our protocol, all patients are treated with midazolam $(0.2 \mathrm{mg} / \mathrm{kg} / \mathrm{h})$ and fentanyl $(0.002 \mathrm{mg} / \mathrm{kg} / \mathrm{h})$ infusions for sedation.

\section{Sample}

Samples were collected using simple random sampling technique and patients were randomly assigned to the intervention and control group. ICP was monitored 2 min before, during and 2 min after ET suctioning in both interventional and control group and readings were noted. Bolus of $2 \mathrm{mg}$ midazolam was given in the interventional group, $1 \mathrm{~min}$ before performing ET suction.

\section{Statistical analysis}

Statistical analysis was performed using SPSS IBM version 19 (IBM Corp. Released 2010. IBM SPSS Statistics for Windows, Version 19.0. Armonk, NY: IBM Corp.).

\section{RESULTS}

A total of twenty male patients were enrolled in the study who were randomly assigned to control and experimental group. There were 10 patients in the midazolam group and 10 patients in control group. A total of 80 readings were obtained from both the groups. As shown in Table 1, both groups were well matched in age, admission GCS, MAP and baseline ICP.
Table 1: Baseline Characteristics of the study subjects

\begin{tabular}{lccc}
\hline Variables & \multicolumn{2}{c}{ Mean \pm SD } & P value \\
\cline { 2 - 3 } & $\begin{array}{c}\text { Intervention } \\
\text { group }(\boldsymbol{n}=\mathbf{1 0})\end{array}$ & $\begin{array}{c}\text { Control } \\
\text { group } \\
(\boldsymbol{n}=\mathbf{1 0})\end{array}$ & \\
\hline Age & $40.20 \pm 12.02$ & $39.27 \pm 12.03$ & 0.83 \\
$\begin{array}{l}\text { Admission } \\
\text { GCS }\end{array}$ & $7.73 \pm 02.25$ & $08.27 \pm 02.63$ & 0.556 \\
$\begin{array}{l}\text { Mean Arterial } \\
\text { pressure }\end{array}$ & $74.8 \pm 05.24$ & $75.6 \pm 06.63$ & 0.7681 \\
Baseline ICP & $16 \pm 2.32$ & $15 \pm 1.89$ & 0.360 \\
\hline ICP=Intracranial pressure, GCS=Glasgow coma scale
\end{tabular}

The mean rise in ICP following ET suctioning in control group was found to be $24.1 \mathrm{mmHg}$ (standard deviation [SD] - 11.1) and was $18.25 \mathrm{mmHg}$ (SD - 9.29) in the midazolam group $(P<0.05)$.

The mean variation of ICP from the baseline value in midazolam group during ET suctioning was found to be $20.8 \mathrm{mmHg}$ (SD - 0.48) and $28.4 \mathrm{mmHg}$ with SD 0.68 in control group $(P<0.05)$.

The time taken for return of ICP to baseline was $15 \mathrm{~min}$ in control group and $10 \mathrm{~min}$ in midazolam group $(P<0.05)$.

\section{DISCUSSION}

In managing patients with severe TBI, it is essential to use techniques and pharmacological agents which do not modify ICP and CPP unfavourably. ${ }^{[3]}$ Sedation is very effective in managing intracranial hypertension and is considered as one of the initial treatment steps, provided that the drugs chosen do not interfere with the cerebral haemodynamics..$^{[5]}$ Several studies advocate neuromuscular blockade to avoid ICP increases after ET suctioning. ${ }^{[-8]}$ However, we reserve neuromuscular blockade for intractable intracranial hypertension. Tateishi et al. have shown that diazepam causes a decrease in MAP and CPP. ${ }^{[9]}$ Following diazepam administration, ICP was maintained when baseline values of ICP were $>15 \mathrm{mmHg}$, but when baseline values were $<15 \mathrm{mmHg}$, ICP decreased. However, this study was conducted in neurosurgical non-injured patients. Midazolam may offer some advantages compared with other benzodiazepines as it is a short-acting, water-soluble agent associated with cardiovascular stability. ${ }^{[10,12,15]}$ Since midazolam is used as first-line sedative agent in TBI patients and is preferred over propofol in patients with haemodynamic instability, we had selected midazolam as an intervention and studied its effectiveness in decreasing the rise of ICP during ET suctioning. ${ }^{[11,13,14,16-21]}$ 
Our study shows that ET suctioning leads to significant rise in ICP despite ongoing sedation and $2 \mathrm{mg}$ bolus of midazolam before suctioning may significantly reduce the rise in ICP. However, significant rise in ICP from baseline may still occur and additional interventions will need to be defined to stabilise ICP during suctioning in these patients.

\section{Financial support and sponsorship Nil.}

\section{Conflicts of interest}

There are no conflicts of interest.

\section{REFERENCES}

1. Heise T. Management of the multiple trauma patient with increased ICP. J Neurosurg Nurs 1983;15:201-4.

2. Adelson PD, Bratton SL, Carney NA, Chesnut RM, du Coudray HE, Goldstein B, et al. Guidelines for the acute medical management of severe traumatic brain injury in infants, children, and adolescents. Chapter 9. Use of sedation and neuromuscular blockade in the treatment of severe pediatric traumatic brain injury. Pediatr Crit Care Med 2003;4 3 Suppl:S34-7.

3. Papazian L, Albanese J, Thirion X, Perrin G, Durbec O, Martin C. Effect of bolus doses of midazolam on intracranial pressure and cerebral perfusion pressure in patients with severe head injury. Br J Anaesth 1993;71:267-71.

4. Cornell JE, Giffin JP, Lim K, Milhorat T, Stein S, Shwiry B. Intracranial pressure, mean arterial pressure and heart rate following midazolam or thiopental in humans with intra cranial masses. Anesthesiology 1982;57:A323.

5. Hanowell LH, Thurston JD, Behrman KH, Disbrow EA. Alfentanil administered prior to endotracheal suctioning reduces cerebral perfusion pressure. J Neurosurg Anesthesiol 1993;5:31-5.

6. Fanconi S, Duc G. Intratracheal suctioning in sick preterm infants: Prevention of intracranial hypertension and cerebral hypoperfusion by muscle paralysis. Pediatrics 1987;79:538-43.

7. Werba A, Weinstabl C, Petricek W, Plainer B, Spiss CK. Requisite muscle relaxation using vecuronium for tracheobronchial suction in neurosurgical intensive care patients. Anaesthesist 1991;40:328-31.

8. Kerr ME, Sereika SM, Orndoff P, Weber B, Rudy EB, Marion D, et al. Effect of neuromuscular blockers and opiates on the cerebrovascular response to endotracheal suctioning in adults with severe head injuries. Am J Crit Care 1998;7:205-17.

9. Tateishi A, Maekawa T, Takeshita H, Wakuta K. Diazepam and intracranial pressure. Anesthesiology 1981;54:335-7.

10. Reves JG, Fragen RJ, Vinik HR, Greenblatt DJ. Midazolam: Pharmacology and uses. Anesthesiology 1985;62:310-24.

11. Barr J, Fraser GL, Puntillo K, Ely EW, Gélinas C, Dasta JF, et al. Clinical practice guidelines for the management of pain, agitation, and delirium in adult patients in the intensive care unit. Crit Care Med 2013;41:263-306.

12. Crutchfield JS, Narayan RK, Robertson CS, Michael LH. Evaluation of a fiberoptic intracranial pressure monitor. J Neurosurg 1990;72:482-7.

13. Moss E, Powell D, Gibson RM, McDowall DG. Effect of etomidate on intracranial pressure and cerebral perfusion pressure. Br J Anaesth 1979;51:347-52.

14. Wolff J. Cerebrovascular and metabolic effects of midazolam and flumazenil. Acta Anaesthesiol Scand Suppl 1990;92:75-7.

15. Giffin JP, Cottrell JE, Shwiry B, Hartung J, Epstein J, Lim K. Intracranial pressure, mean arterial pressure, and heart rate following midazolam or thiopental in humans with brain tumors. Anesthesiology 1984;60:491-4.

16. Chan KH, Miller JD, Dearden NM, Andrews PJ, Midgley S. The effect of changes in cerebral perfusion pressure upon middle cerebral artery blood flow velocity and jugular bulb venous oxygen saturation after severe brain injury. J Neurosurg 1992;77:55-61.

17. Urwin SC, Menon DK. Comparative tolerability of sedative agents in head-injured adults. Drug Saf 2004;27:107-33.

18. Skoglund $K$, Enblad $P$, Hillered L, Marklund $N$. The neurological wake-up test increases stress hormone levels in patients with severe traumatic brain injury. Crit Care Med 2012;40:216-22.

19. Burry L, Rose L, McCullagh IJ, Fergusson DA, Ferguson ND, Mehta S. Daily sedation interruption versus no daily sedation interruption for critically ill adult patients requiring invasive mechanical ventilation. Cochrane Database Syst Rev 2014;9;7:CD009176.

20. Skoglund K, Enblad P, Marklund N. Effects of the neurological wake-up test on intracranial pressure and cerebral perfusion pressure in brain-injured patients. Neurocrit Care 2009;11:135-42.

21. Heffernan DS, Inaba K, Arbabi S, Cotton BA. Sympathetic hyperactivity after traumatic brain injury and the role of beta-blocker therapy. J Trauma 2010;69:1602-9. 